\title{
QUALITATIVE ASPECTS OF POPULATION CONTROL: EUGENICS AND EUTHENICS
}

\author{
FrEDERICK OsborN*
}

A visitor from outer space, considering our planet today, might well conclude that the most important recent development of man's activities on earth was his control of deaths and his control of births. These two interrelated phenomena between them determine man's numbers and in many ways affect his quality. On anything like their present scale, they are of very recent origin.

$\mathrm{U}_{\mathrm{p}}$ to the beginning of the nineteenth century, an average length of life of thirty-five to forty years may have been common in various localities among civilized nations. By Igor, expectation of life in Massachusetts had risen to over forty-six years for men and forty-nine years for women. Today in the United States, it is over sixty-seven years for men and over seventy-two years for women. ${ }^{1}$

The first widespread practice of fertility control took place in France in the early part of the nineteenth century, but it was not until the Bradlaugh-Besant trials in England in $1877^{2}$ that "antifertility" practices became widely used and began to gain public acceptance. Today in the United States, according to the most recent studies, over eighty-five per cent of married women practice some form of fertility control, and births have fallen to 2.3 per woman of completed fertility in 1958, as compared to five per woman at the turn of the century. ${ }^{3}$ Similar changes have more recently taken place in the Soviet Union and even more recently in Japan.4

But in the rest of the world, the picture is very different. By the use of serums, antibiotics, and insecticides, death rates can now be dramatically reduced, as they have been in Ceylon, Malaya, the Caribbean area, Venezuela, and Chile. These countries experienced in less than a decade a decline in death rates that it took the western world half a century to achieve. But while death rates are going down

* A.B. Igro, Princeton University; post grad. study rgrI-12, Trinity College, Cambridge, Eng.; LL.D. 1943, Washington \& Lee University; IL.D. r947, Washington \& Jefferson College; Sc.D. r942, Norwich University; Litt.D. 1945, New York University. Chairman, Executive Committee, The Population Council, Inc. Author, [with Frank Lorimer] Dynamics of Population (r934); Prepace to Euoenics (1940). Editor, G. C. Schwesinger, Heredity and Environment (1933). Contributor to population periodicals.

${ }^{1}$ Louis I. Dublin, Alfred J. Lotka \& Mortimer Spiegelman, Length of Life 56, 65 (rev. ed. 1949).

${ }^{2}$ R. v. Bradlaugh \& Besant, 2 Q.B.D. 569 (I877), rev'd, 3 Q.B.D. 607 (C.A. I878).

${ }^{3}$ Ronald Freedman, Pascal K. Whelpton \& Arthur A. Campbell, Family Plannino, Sterility, and Population Growth 64 (1959).

'U.N. Dep'r of Economic and Soctal Affairs, Demographic Yearbook 21t, 215 (U.N. Pub. Sales No. I958, XIII. I). 
rapidly in some areas, and at a slower tempo in others, birth rates in the underdeveloped regions of the world remain at medieval levels.

As a result of the widening gap between births and deaths in the economically underdeveloped countries, we are faced with rapid changes in the proportion of peoples brought up in different cultures, as is evident from table one. According to these United Nations estimates, the proportion of Europeans to the total world population is likely to go down in fifty years from 15.7 per cent to nine per cent, the proportion of Russians from 7.2 per cent to six per cent, the proportion of North Americans from 8.8 per cent to 8.1 per cent, while the proportion of Asians is expected to increase by II.5 per cent and the proportion of South Americans by forty per cent. This is in great contrast to the changes that took place during the previous 300 years, when people of European descent increased sevenfold as against a fourfold increase for the rest of the world.

TABLE I

Growth and Distribution of World Population

\begin{tabular}{|c|c|c|c|}
\hline \multirow{2}{*}{ Ares } & \multirow[b]{2}{*}{1950} & \multicolumn{2}{|c|}{ Medium Estimates } \\
\hline & & 1975 & 2000 \\
\hline World total (millions) . . . . . . & \multicolumn{3}{|c|}{$2500 \underset{\text { Percentage Distribution }}{\mid} 3830 \quad 6280$} \\
\hline 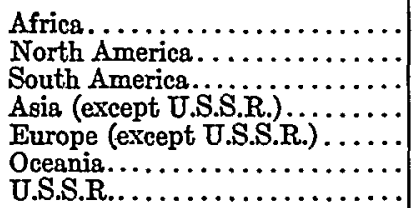 & $\begin{array}{r}8.0 \\
8.8 \\
4.5 \\
55.2 \\
15.7 \\
.5\end{array}$ & $\begin{array}{r}7.9 \\
8.8 \\
5.3 \\
57.7 \\
12.4 \\
.5 \\
7.2\end{array}$ & $\begin{array}{r}8.2 \\
8.1 \\
6.3 \\
61.6 \\
9.0 \\
.5\end{array}$ \\
\hline
\end{tabular}

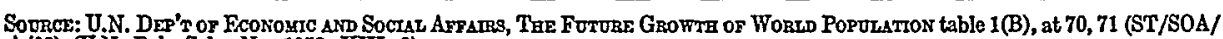
Ser.A/28) (U.N. Pob. Sales No. 1958. XIII. 2).

In so far as different cultures give their people different qualities and social values, these changes in proportionate numbers are changes in the quality of the whole. They are brought about by the present uneven spread of death control and birth control throughout world populations. It seems likely that birth rates will eventually go down among all the world's peoples, as they have already among the people of the more industrialized countries. The present large variations in rates of increase would then become matters of historical interest. But other trends in population might still be having an important part in determining the quality of people everywhere.

\section{The Extent to Which Population Trends May Determane Quality}

The quality of the people in any community or nation is determined by a number of factors, which include cultural and environmental influences, the kind of homes the children are brought up in, the kind of parents who bring them up, and the 
genetic factors derived from the parents. Each of these conditions may be affected by population trends--that is, by trends in rate of growth, mating habits, differential death and birth rates, and migration. A rapid rate of growth may make it more difficult to provide educational facilities, provide cultural and recreational opportunities, and expand production; mating habits may affect the rate of growth, or modify genetic and cultural inheritance; differential fertility may increase the number of people in particular racial, social, or occupational groups; differences in size of family between couples with different personal qualities will affect the proportion of people with similar qualities in the next generation, since people tend to be like their parents; and both internal and external migration may affect quality in many ways. The relative importance of these different influences is not easily assessed. It must vary with every change in circumstance.

\section{A. Less-Industrialized Countries}

The concern of society for improving the quality of our people is expressed chiefly in expenditure for education, public health, housing, recreational facilities, and other things outside the home. The extent of advances in these fields may be greatly affected by the rate of population growth. If population is increasing more rapidly than production, as is the case in a number of countries today, per capita income is reduced and the level of living declines. Each year there are fewer goods available per person, and quite evidently it is harder to find the money for education and other cultural needs. Further, when a population is growing rapidly, the proportion of children is high and the proportion of the labor force low as compared to the proportions in a static population. In the United States in 1940, following on the low birth rates during the depression, there was one child under fourteen years of age to every three adults (twenty-five per cent to seventy-five per cent); by comparison, in 1880 , when the population was growing rapidly, the proportion was two children to every three adults (38.I per cent to 61.9 per cent), a proportion similar to that in India today. ${ }^{5}$

In a highly productive economy like that of the United States, these differences are not of major importance. There is plenty of margin for improving educational and other facilities if the people really want it done. But in a country like India, where the barest necessities are hard to come by, a low proportion of people in the labor force and a high proportion of mouths to feed may be a serious handicap to any accumulation of capital and to improving educational and other facilities, a handicap so serious as to make it extremely difficult, if not quite impossible, for a country with a low per capita productivity to pull itself up by its own bootstraps.

Coale and Hoover, in a recent study of economic trends in India, came to the following conclusions, after taking into account the rapid advances in agriculture and manufacture that may be expected in the next thirty years: If there are con-

${ }_{2}$ U.S. Bureau of the Census, Dep't of Commerce, i950 Census of Population pt. I, table 39 (1953). 
tinued declines in mortality, but no decline in fertility, the population of India should reach $775,000,000$ by $I 986$, and by then, average income per consumer would be growing at a rate of less than one per cent per year. If the declining mortality were accompanied by a fifty per cent decline in fertility between 1956 and I981, the population of India should reach $590,000,000$ by 1986 , and average income per consumer would then be forty per cent higher than that attained under the high-fertility assumption and rising at the rate of 3.4 per cent per year. ${ }^{6}$

Such considerations have led to the widely-held theory that rapid increases in population are a serious handicap to economic growth in countries of low productivity, such as India. This is not to say that new ideas do not spread in an underdeveloped economy. Modern methods of communication and transportation are helping to change the attitudes and aspirations of the world's peoples at a fantastic rate, and at little cost. But educational and cultural facilities are not growing as fast, and in this respect, rapid growth in a weak economy is undoubtedly a retarding factor. It may, therefore, be worth while to look at rates of population increase among some of the world's people for their effect on increases in production and thus on the accumulation of educational and cultural facilities.

TABLE II

World Population and Rates of Increase

\begin{tabular}{|c|c|c|c|c|c|}
\hline \multirow{2}{*}{ Area } & \multirow{2}{*}{$\begin{array}{c}\text { Annual Rate } \\
\text { of Increase } \\
\text { (1953-57 aver- } \\
\text { age percentage) }\end{array}$} & \multicolumn{2}{|c|}{$\begin{array}{c}\text { Annual Rates / } 1000 \text { Popúlation } \\
\text { (1953-57 average) }\end{array}$} & \multirow{2}{*}{$\mid \begin{array}{c}\text { Population, } \\
1959 \\
\text { (millions) }\end{array}$} & \multirow{2}{*}{$\underset{\substack{\text { Estimates, 2000 } \\
\text { (millions) }}}{\text { N. }}$} \\
\hline & & Births & Deaths & & \\
\hline World total. ......... & 1.6 & 34 & 18 & 2896 & 6280 \\
\hline 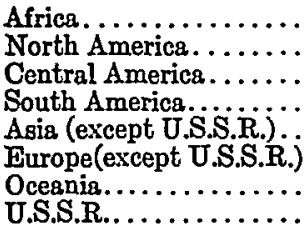 & $\begin{array}{l}1.8 \\
1.6 \\
2.6 \\
2.3 \\
1.8 \\
0.8 \\
1.6 \\
1.8\end{array}$ & $\begin{array}{l}45 \\
25 \\
41 \\
39 \\
39 \\
19 \\
25 \\
25\end{array}$ & $\begin{array}{r}27 \\
9 \\
15 \\
16 \\
21 \\
11 \\
9 \\
7\end{array}$ & $\begin{array}{r}234 \\
196 \\
65 \\
134 \\
1621 \\
421 \\
16 \\
209\end{array}$ & $\begin{array}{r}517 \\
312 \\
198 \\
394 \\
3870 \\
568 \\
29.3 \\
379\end{array}$ \\
\hline
\end{tabular}

SoUrczg: U.N. Dep't or Econoutc ano Soctad AfFaIrs, Demographic Yaarboox table 2, at 104 (U.N. Pub. Sales No. 1958. XII. 1);

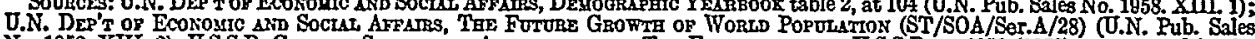
No. 1959. XIII. 2); U.S.S.R. CENTRAT, STATISTICAL ADYIISETRATION, TEE ECONOYY OF TEE U.S.S.R. nN 1958 (1959), as reported in the N.Y. Times, Oct. 16, 1959, p. 2, col. 3.

From the figures in table two, it is clear that the most rapid increases in numbers are presently taking place in areas that have a minimum of industrial plant and a culture and level of training that will make technical improvement a slow process. Death rates are still high in these areas, and as they go down, population will increase even more rapidly than at present, until there is a corresponding fall in births. It is in such areas that rapid population growth may be considered a serious handicap to improving levels of living. Many people believe that the problems thus created are among the most important facing the world today.

- ansley J. Conle \& Edgar M. Hoover, Population Growth and Economic Development in LOW-INCOME COUNTRIES 284, 286 (I958). 


\section{B. United States}

\section{The effect of growth in numbers}

In the United States, the present rate of increase is fairly high, about I.5 per cent a year, about the same as the increase now taking place in India. But the conditions are very different. Our land is not crowded, as is India's. Our low death rate, which is attributable in part to the present age distribution of the population, will go up as the proportion of old people increases. We are heavily industrialized, and technological improvements are taking place at a cumulative rate, so that productive capacity is quite sure to increase at a faster rate than population. Economists seem to be divided in their opinions as to the effect of population growth under these conditions. Some feel that it has a retarding effect on the improvement of levels of living. Others hold that growth is a stimulus to enlargement of plant and a psychological stimulus to increased economic activity, and is hence on the whole beneficial.

Whatever the true answer, it seems to the present writer that current rates of increase are not likely to continue indefinitely in this country. The baby boom started at the end of World War II, following a continuous decline in births over the past hundred years, as is shown in table three. The boom was magnified by a high marriage rate to make up the gap during the war and by a decline in age at marriage. Any deterioration of economic conditions might well see a return to the lower prewar birth rates, such as has occurred in Europe since r955.

TABLE III

UNITED States Rates of Growth, I790-I960

\begin{tabular}{|c|c|c|c|}
\hline Year & $\begin{array}{l}\text { U.S. Population } \\
\text { (thousands) }\end{array}$ & $\begin{array}{l}\text { Increase over } \\
\text { Previous Decade } \\
\text { (percentage) }\end{array}$ & $\begin{array}{l}\text { Average Annual Rate } \\
\text { during Previous Decade } \\
\text { (percentage) }\end{array}$ \\
\hline 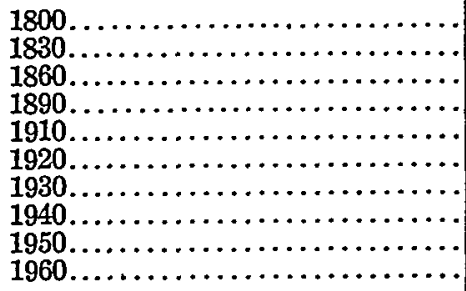 & $\begin{array}{r}5,308 \\
12,866 \\
31,443 \\
62,948 \\
91,972 \\
105,711 \\
122,775 \\
131,669 \\
151,132 \\
179,000\end{array}$ & $\begin{array}{r}35.1 \\
33.5 \\
35.6 \\
25.5 \\
21.0 \\
14.9 \\
16.1 \\
7.2 \\
14.5 \\
18.4\end{array}$ & $\begin{array}{l}3.1 \\
2.9 \\
3.2 \\
2.3 \\
1.9 \\
1.4 \\
1.5 \\
0.7 \\
1.4 \\
1.7\end{array}$ \\
\hline
\end{tabular}

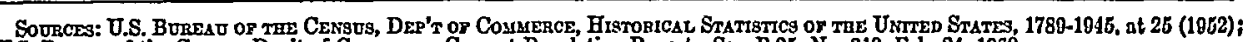
U.S. Bureau of the Census, Dep't of Commeree, Current Population Reports, Ser. P-25, No. 213, Feb. 24, 1860 .

During the period 1800 to the present, the death rate per thousand population fell gradually from about twenty-five ${ }^{7}$ to $9.4^{8}$ The birth rate fell somewhat later. Between I9ro and 1950 , the average number of children ever born to white women forty-five to forty-nine years of age declined from 4.I to 2.3, and that for nonwhite

"Wilson H. Grabili, Clyde V. Kiser \& Pascal K. Whelpton, The Fertility of American Women 7 (1958).

${ }^{8}$ U.S. Dep't of Health, Education, and Welfare, Monthly Vital Statistics Report, Feb. 1960, p. I. 
women declined from 5.9 to 2.7. Then almost before World War II was over, came the baby boom, a phenomenon that took place mostly in the white-collar groups that had had the lowest birth rates during the depression. Among the rural and lower-income groups, whose large families had contributed a large proportion of the growth in previous decades, the proportion of families of five or six or more continued to fall.

In the twenty-five-year period covered in table four, the proportion of fifth and higher order births fell from 26.3 per cent to fifteen per cent of all births, and the proportion of eighth and higher births fell by more than half. The table does not tell the final story, however, for the women who completed their childbearing in I958 at forty-four years of age had, in most cases, been married during the depression and were affected by the baby-boom psychology only as they were reaching the age of thirty. They are the most recent cohort for which completed birth figures are available. Analysis of the birth rates for younger women married in the postwar years indicates an increase in second, third, and fourth births and a possible increase in fifth births before childbearing is completed, but a continuous decline in births of six or more.

TABLE IV

United States Cumulative Births per 1,000 Women Aged 44 Years, i933-58

\begin{tabular}{|c|c|c|c|c|c|c|}
\hline & \multicolumn{6}{|c|}{ Women Born in: } \\
\hline & 1914 & 1909 & 1904 & 1899 & 1894 & 1889 \\
\hline 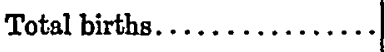 & 2324.7 & 2220.2 & 2382.0 & 2607.9 & 2899.6 & 3152.9 \\
\hline 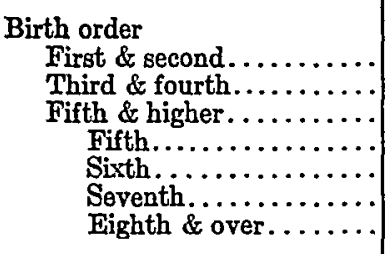 & $\begin{array}{r}60.3 \\
24.7 \\
15.0 \\
5.4 \\
3.4 \\
2.2 \\
4.0\end{array}$ & $\begin{array}{r}59.5 \\
24.0 \\
16.5 \\
5.6 \\
3.7 \\
2.5 \\
4.7\end{array}$ & $\begin{array}{c}\text { Percent } \\
57.0 \\
24.4 \\
18.6 \\
6.2 \\
4.2 \\
2.8 \\
5.4\end{array}$ & $\begin{array}{c}\text { of Total } \\
\text { 53.0 } \\
25.7 \\
21.3 \\
6.9 \\
4.9 \\
3.3 \\
6.2\end{array}$ & $\begin{array}{r}50.1 \\
26.5 \\
23.4 \\
7.4 \\
5.3 \\
3.7 \\
7.0\end{array}$ & $\begin{array}{r}46.6 \\
27.1 \\
26.3 \\
8.1 \\
5.9 \\
4.1 \\
8.2\end{array}$ \\
\hline Year of attaining age $44 . \ldots$. & 1958 & 1953 & 1948 & 1943 & 1938 & 1933 \\
\hline
\end{tabular}

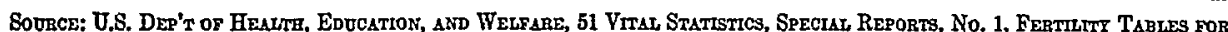
Burth CoHohts of AMERICAN WOMEN table 4 (1960).

If the growth rate of recent years continues through the next century, the United States could have a population of $x, 000,000,000$ by 2050 . But such an event seems unlikely. Birth rates will probably level off, but the United States seems headed for a population of about $240,000,000$ by $1980,{ }^{10}$ and may even reach $300,000,000$ in another forty years. ${ }^{11}$ Even such an increase should not seriously threaten our level of living or our ability to provide educational and cultural facilities, provided

${ }^{\circ}$ Grabill, Kiser \& Whelpton, op. cit. stipra note 7 , at 46.

${ }^{10}$ U.S. Bureau of the Census, Dep't of Commerce, Current Population Reports, Ser. P-25, No. 187 , Nov. I0, 1958 , p. 16.

${ }^{2}$ U.N. Dep't of Economic and Social Affars, The Future Growth of World Population jo (ST/SOA/Ser. A/28) (U.N. Pub. Sales No. 1958.XIII.2). 
our people put some limit on their consumption of consumer goods. Many people think life will not be so attractive in so crowded a country and fear for our educational, political, and cultural institutions under such a piling up of population. These apprehensions will certainly not diminish if we begin to approach the $600,000,000$ or $1,000,000,000$ people for whom our area could provide a good sustenance.

2. The effect of birth differentials between occupational, socioeconomic, and rttralurban groups

Various aspects of quality are represented by the farmer and the city dweller, by the college graduate and the person who has had only three years of grade school, by the laborer, the mechanic, and the executive, and by those with good incomes and those at the bottom of the economic scale. Differences in the birth rates of such groups have attracted much interest for the changes they may make in the proportions of each type in succeeding generations. It is hard to deny the possibility that such differentials may have an important effect, for the children of the moreeducated, professional, and higher-income classes reach positions of leadership far more frequently than might be expected from their number. But our great social mobility, the constant rise in our level of living, the educational opportunities open to all who are qualified, may mask the effect of fertility differentials.

There is much evidence that in earliest times, the rural populations increased more rapidly than those in the cities, partly perhaps because of the higher death rates in the cities. But for the past fifty years, death rates have not varied to any great degree between city and country or between occupational groups. Births are now almost the only factor in the increase or decline of various groups of the population. Further, many major studies in recent years have made it clear that differences in fertility between large groups of the population are not attributable to differences in fecundity-i.e., in the ability to have children-but are attributable almost wholly to the voluntary control of fertility.

\section{TABLE V}

Children Born in the United States per yoo Wives Aged 40-44 Years by Broad Occupational Classes, igio

\begin{tabular}{|c|c|c|}
\hline Occupational Class & $\begin{array}{l}\text { Rates for } \\
\text { Each Class }\end{array}$ & $\begin{array}{l}\text { Ratio of Each Class to } \\
\text { Total Urban or Rural }\end{array}$ \\
\hline 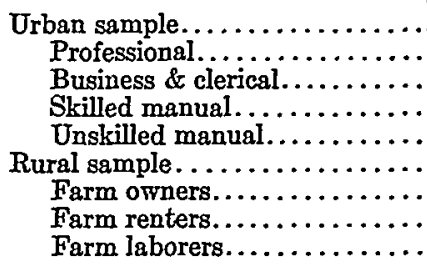 & $\begin{array}{l}249 \\
211 \\
224 \\
277 \\
334 \\
402 \\
376 \\
467 \\
471\end{array}$ & $\begin{array}{r}100 \\
85 \\
90 \\
111 \\
134 \\
100 \\
94 \\
116 \\
117\end{array}$ \\
\hline
\end{tabular}

Sotrce: Adapted from Sydenstricker \& Notestein, Differential Pertitity According to Social Class, 25 J. Au. STat. Ass's 24, 25 (1030) 
As is seen in table five, urban wives who had completed their childbearing by Igro had produced only sixty-two per cent of the number of children born to rural wives; the wives of professional and business men, less than half the number born to the wives of farm renters and farm laborers. Between I9ro and 1940, birth rates fell in all these groups, but there was no great change in differentials between the classes until the end of World War II. Immediately following the war, birth rates went up rapidly, but chiefly among the white-collar classes, who had most limited their rate of births during the depression. The manual unskilled labor group, rural and urban, showed no comparable increase. Women married during. the baby boom have not yet completed their period of fertility, but recent data indicate a considerable narrowing of differentials, as is shown in table six.

\section{TABLE VI}

Children Born in the United States per 100 Wives Aged $15-44$ by Residence and Occupation, 1957

\begin{tabular}{|c|c|c|c|c|c|}
\hline \multirow{3}{*}{ Status } & \multicolumn{2}{|c|}{1975} & \multirow{3}{*}{1950} & \multirow{2}{*}{\multicolumn{2}{|c|}{$\begin{array}{l}\text { Intragroup } \\
\text { Standing }\end{array}$}} \\
\hline & \multirow{2}{*}{$\begin{array}{l}\text { Unstand- } \\
\text { ardized }\end{array}$} & \multirow{2}{*}{$\begin{array}{l}\text { Standardized } \\
\text { for Age }\end{array}$} & & & \\
\hline & & & & $1957^{\mathrm{A}}$ & 1950 \\
\hline \multirow[t]{2}{*}{ 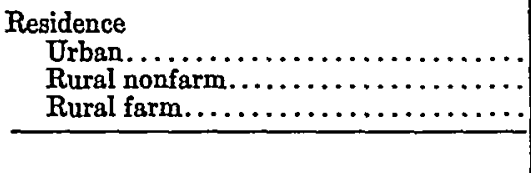 } & $\begin{array}{l}204 \\
236 \\
301\end{array}$ & $\begin{array}{l}201 \\
233 \\
293\end{array}$ & $\begin{array}{l}163 \\
214 \\
265\end{array}$ & $\begin{array}{l}100 \\
116 \\
146\end{array}$ & $\begin{array}{l}100 \\
132 \\
163\end{array}$ \\
\hline & & & 1952 & 1957 & 1952 \\
\hline 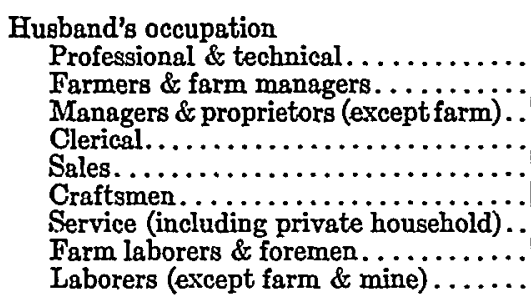 & $\begin{array}{l}200 \\
315 \\
221 \\
188 \\
206 \\
233 \\
228 \\
373 \\
265\end{array}$ & $\begin{array}{l}194 \\
302 \\
209 \\
192 \\
203 \\
228 \\
223 \\
-270\end{array}$ & $\begin{array}{l}165 \\
270 \\
176 \\
157 \\
154 \\
193 \\
181 \\
238\end{array}$ & $\begin{array}{r}64 \\
100 \\
69 \\
64 \\
67 \\
75 \\
76 \\
\frac{-}{89}\end{array}$ & $\begin{array}{r}61 \\
100 \\
65 \\
58 \\
57 \\
71 \\
67 \\
\frac{88}{8}\end{array}$ \\
\hline
\end{tabular}

Norz: * Standardized by age distribution of earlier period for comparison.

Source: U.S. Bureau of the Census, Dep't of Commerce, Current Population Reports, Ser. P-20, No. 84, Aug. 8, 1958 , tables 4 and 5.

During the past fifteen years, the country has been seeing the cumulative effect of those forces that are dulling the lines between "urban" and "nonurban" peoples. and tending to produce a single type of urbanized society, all subject to the same kinds of environmental pressures and exhibiting the same kind of social behavior.. This process is not yet complete, and the period since 1945 is too short for decisive figures on the change in fertility rates. Freedman, Whelpton, and Campbell, in their recent book, Family Planning, Sterility, and Population Growth, indicate their belief that ${ }^{12}$

\footnotetext{
${ }^{12}$ FreedMan et aL., op. cit. supra note 3, at 273.
} 
in the United States we now seem to have reached a phase of demographic evolution where fertility differentials are smaller than they were a few decades ago. Some of the differentials such as those associated with income, education, and place of residence, even show signs of disappearing.

Their findings indicated that couples with annual incomes of $\$ 7,000$ or more had had 2.3 children and were expected to end up with 2.9. Couples with annual incomes under $\$ 3,000$ had had 2.0 children and were expected by the end of childbearing to have 3.2. Seventy-nine per cent of those with annual incomes over $\$ 6,000$ were using contraception at the time of the survey. Those with annual incomes under $\$ 3,000$ were younger, and only fifty-eight per cent were using contraception. ${ }^{13}$

Future trends are hard to forecast, and we may better consider the actual situation of the $62,500,000$ children under eighteen who are living in the United States today. Of these children, all but something less than 1,000,000 live with their 26,500,000 families. (There are an additional $77,700,000$ families with no children.) Some 25,600,000 (41.6 per cent) of these children are in families of one or two children; 24,000,000 (thirty-nine per cent) are in families with three or four children; and I2,000,000 ( 19.4 per cent) are in larger families of five or more children. The families with more than two children are at progressively lower income levels according as they have three, four, five, or six or more children, as is shown in table seven.

TABLE VII

Distribution of Children in the United States, 1958

\begin{tabular}{|c|c|c|c|c|c|}
\hline \multirow[b]{2}{*}{ CHIIDREN PER F FMILY } & \multicolumn{2}{|c|}{ Fastines } & \multicolumn{2}{|c|}{ CHILDREN } & \multirow[b]{2}{*}{$\begin{array}{c}\text { MEDIAN } 1958 \\
\text { FAXILYX INCOAK }\end{array}$} \\
\hline & $\begin{array}{l}\text { Number } \\
\text { (thousands) }\end{array}$ & $\begin{array}{l}\text { Percentage } \\
\text { of Total }\end{array}$ & $\begin{array}{c}\text { Number } \\
\text { (thousands) }\end{array}$ & $\begin{array}{l}\text { Percentage } \\
\text { of Total }\end{array}$ & \\
\hline 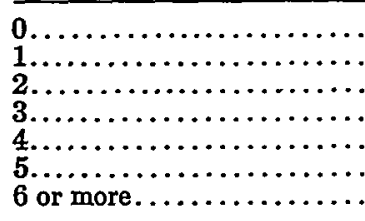 & $\begin{array}{r}17,714 \\
8,771 \\
8,410 \\
4,844 \\
2,376 \\
1,102 \\
985\end{array}$ & $\begin{array}{r}40.1 \\
19.8 \\
19.0 \\
11.0 \\
5.4 \\
2.5 \\
2.2\end{array}$ & $\begin{array}{r}0 \\
8,771 \\
16,820 \\
14,532 \\
9,504 \\
5,510 \\
6,480\end{array}$ & $\begin{aligned} 0 \\
14.2 \\
27.4 \\
23.6 \\
15.4 \\
8.9 \\
10.5\end{aligned}$ & $\begin{array}{r}\overline{\$} \\
\$ 5288 \\
5580 \\
5451 \\
5042 \\
4430 \\
3481\end{array}$ \\
\hline Total........ & 44,202 & 100.0 & 61,617 & 100.0 & $\$ 5123$ \\
\hline
\end{tabular}

Sourcy: U.S. Bureau of the Census, Dep't of Commerce, Current Population Reports, Ser. P-60, No. 33, Jan. 15, 1960, tablo 0.

Table eight, which is more detailed, indicates that in 1958 , there were 3,200,000 children in families whose annual income was under $\$ \mathrm{r}, 000$, and an additional $10,500,000$ in families whose annual income was between $\$ 1,000$ and $\$ 3,000$. A total of $13,500,000$, or twenty-three per cent of all our children, were brought up in families with annual incomes below $\$ 3,000$. A third of these children were in families with five or more children. At the other extreme, only eleven per cent of the 5,200,000 children whose families have an annual income of $\$ 10,000$ or more are in families of five or more children. Fifty-eight per cent of the two-child families had annual

${ }^{13} \mathrm{Id}$. at $124,296$. 
TABLE VIII

Distribution of Children in the United States by Family Income, I958

\begin{tabular}{|c|c|c|c|c|c|c|c|c|c|c|c|c|}
\hline \multirow{3}{*}{ Cutldres per Faumly } & \multirow{2}{*}{\multicolumn{2}{|c|}{ 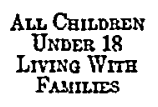 }} & \multicolumn{10}{|c|}{ Total Anntal Income Per Fauml } \\
\hline & & & \multicolumn{2}{|c|}{ Under $\$ 1000$} & \multicolumn{2}{|c|}{$\$ 1000-\$ 3000$} & \multicolumn{2}{|c|}{$\$ 3000-\$ 5000$} & \multicolumn{2}{|c|}{$\$ 5000-\$ 7000$} & \multicolumn{2}{|c|}{$\$ 7000 \&$ Over } \\
\hline & 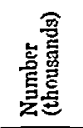 & 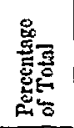 & 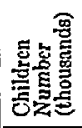 & 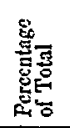 & 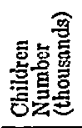 & 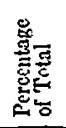 & 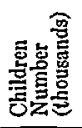 & 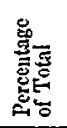 & 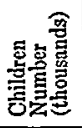 & 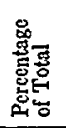 & 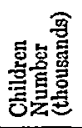 & 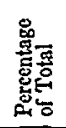 \\
\hline $1, \ldots \ldots \ldots . . . \ldots$ & 8.771 & 14.2 & 421 & 13.1 & 1,465 & 14.0 & 2,184 & 13.6 & 2,193 & 13.2 & 2,503 & 16.4 \\
\hline $2 \ldots \ldots \ldots \ldots \ldots \ldots$ & 16,820 & 27.4 & 572 & 17.9 & 2,086 & 19.9 & 4,322 & 26.9 & 4,928 & 29.7 & 4,912 & 32.1 \\
\hline $3 . \ldots \ldots \ldots \ldots \ldots$ & 14,532 & 23.6 & 597 & 18.6 & 1,947 & 18.6 & 3,735 & 23.2 & 4,374 & 26.4 & 3,879 & 25.4 \\
\hline & 9,504 & 15.4 & 448 & 14.0 & 1,652 & 15.8 & 2,596 & 16.1 & 2,640 & 15.9 & 2,168 & 14.2 \\
\hline $5 \ldots \ldots \ldots \ldots \ldots$ & 5,510 & 8.9 & 460 & 14.4 & 1,205 & 11.5 & 1,525 & 9.5 & 1,355 & 8.2 & 965 & 6.3 \\
\hline 6 or more............... & 6,480 & 10.5 & 706 & 22.0 & 2,120 & 20.2 & 1,720 & 10.7 & 1,085 & 6.5 & 849 & 5.6 \\
\hline Total. ............ & 61,617 & 100.0 & 3,204 & 100.0 & 10,475 & 100.0 & 16,082 & 100.0 & 16,575 & 100.0 & 15,281 & 100.0 \\
\hline Percentage of total..... & 100.0 & & 5.2 & & 17.0 & & 26.1 & & 26.9 & & 24.8 & \\
\hline
\end{tabular}

Sounce: U.S. Bureau of the Census, Dep't of Commerce, Current Population Reports, Ser. P-60, No. 33, Jan. 15, 1960, table 6.

incomes of $\$ 5,000$ or more, and fifty-seven per cent of the three-child families were in this category, while sixty-three per cent of the families with five or more children had annual incomes below $\$ 3,000$. For the country as a whole, the smaller the family income, the larger the number of children among whom it must be divided.

Adequate income is not by any means the only thing necessary for rearing children, but a really inadequate income is almost certain to hamper their physical growth and provide insufficient stimulus to mental growth. Several attempts have been made to determine the cost of "minimum but adequate" levels of living. The best known is the United States Bureau of Labor Statistics' City Worker's Budget, representing a "modest but adequate" level of living to ensure health, efficiency, social participation, and self-respect for a husband aged thirty-eight, his wife, a son of thirteen, and a daughter of eight. The Bureau is in the process of bringing this budget up to date, since it was compiled on the basis of prewar standards and was last priced in thirty-four major cities in October I95I. By applying the increase in the Consumer Price Index since October 195I, however, the figure of almost $\$ 5,000$ is the minimum annual income required in any urban area to provide for a family of four, including two children, adequately but modestly, even on the prewar standard.

Table eight indicates that 48.3 per cent of the children are in families where the I958 annual income was under $\$ 5,000$. Of course, many of these are rural families whose cash requirements are considerably less than those of urban dwellers. By assuming that all the $8,200,000$ farm children are in families of $195^{8}$ annual income under $\$ 5,000$, we find there are at least $10,500,000$ urban and rural nonfarm children living in families of three or more children where the $195^{8}$ annual income was under $\$ 5,000$. For at least twenty per cent of the nation's children, therefore, the 
family income is inadequate, while at the same time, the adults with whom the children have contact in the home have, in most cases, a very limited educational attainment.

Very little is known about average differences in genetic inheritance between different economic and social classes. The subject has had much attention, and the results are inconclusive. There is at present no sufficient scientific basis for believing that the higher birth rates of the people in the lower-income groups (but not including the socially inadequate) are causing a genetic deterioration from one generation to another. These children, however, contribute far less than their proportions to the skills and leadership of their generation. Whether their relative inadequacy has environmental or genetic origins or results from a combination of both, their social contribution is less than that of children born and brought up in homes at a higher income level. To this extent at least, the present effect of population control is injurious to quality.

\section{The role of personal characteristics of intelligence, personality, character, and health}

Even more than with group differences, the quality of the population might be much affected by differences in size of family as between couples of varying personal qualities. The personal characteristics of individuals, their health, their intelligence, their personality and character tend to be like those of their parents. There are many exceptions, of course, because different genetic types within the same families may react very differently to the same home environment. But the general similarity of children to their parents has been confirmed by many studies. Tyler says, "Practically all investigators agree that the intra family correlations for intelligence test scores are of a magnitude comparable to those for structural physical traits. They center around .50 for both characteristics."14 In summarizing an exhaustive study of the work in this field in the past forty years, Anastasi says, ${ }^{15}$

Correlations between tests of siblings cluster around .50. In personality characteristics, correlations are somewhat lower. Husband-wife correlations tend to follow a similar pattern. Available evidence indicates that such marital correlations result largely from assortative mating rather than from common experiences and mutual influence of the spouses after marriage.

Since children tend to be like their parents, any difference in the number of children born to parents of different types will correspondingly change the proportion of people having those qualities in the next generation. For the purpose of the study of the effect of population control on quality, it does not matter whether the quality is one which is almost wholly determined by heredity-as, for instance, eye color-or whether the quality is one that varies with training-as, for instance, intelligence as shown by intelligence tests; the result is the same, since the qualities are passed on to the next generation.

${ }^{14}$ Leona E. Tyler, The Psychology of Human Differences 484 (1956).

${ }^{15}$ A. ANastast, Differential Psychology 309 (1958). 
Personal qualities of intelligence, personality, health, and vitality are widely scattered throughout the population. They are not part of a culture pattern, in the sense that rural, urban, and occupational groups represent particular culture types, but they are spread widely through every type of culture. These qualities are more enduring than culture patterns. In our American society, people change easily and in great numbers from one occupational or social group to another, but the personal qualities of their parents are likely to stay with them for life. These qualities are more important than culture patterns, because these qualities maintain the best in the culture and are capable of evolving new and higher cultures. Many people believe that civilizations rise and fall according to the proportion they contain of people of high intelligence, fine personality, strong character, and good health. If the control of births affects these proportions, it would be wisdom for us to know that it does, and to know in what way it affects them.

Unfortunately, very little is known about the distribution of births according to the personal characteristics of the parents. These qualities are hard to measure, and to measure them in a large enough number of people to make up an adequate sample of the total population is exceedingly expensive. This is in great contrast to the ease with which demographers study trends among occupational groups, whose numbers are neatly listed by the census.

a. Fertility at the upper levels of quality. At the upper levels of quality, there are several classifications available that have been studied at different intervals and from which we may derive an indication of the trends resulting from the present widespread control of births. Men and women are listed in Who's Who because they have achieved something that in our form of society is considered important. The student of trends in births does not in this case have to make judgments on questions of quality; they have been made for him by the judgment of society. In a recent study of the number of children of men in Who's Who, Kirk found that "the fertility of younger men in Who's Who is probably now equal to or above the national average of the white population"; for the whole group, completed fertility is about at the replacement level. ${ }^{16}$ This is in marked contrast to the results of a similar study made thirty years ago. ${ }^{17}$ At that time, the national birth rate was much higher than at present, but the completed fertility of men in Who's Who was about half that needed for replacement. Today's Who's Who men show a remarkable homogeneity with respect to marriage and family size. Almost all who have been married (ninety-four per cent have been married at least once) have had two- or three-child families. Differential factors are: r) religion, and 2) negative relation between fertility and social mobility.

Graduation from college is another classification that is available and has been used by demographers. It is not as good as listing in Who's Who, because chance ${ }^{10}$ Dudley Kirk, Fertility of a Gifted Group: A Study of the Number of Children of Men in "Who's Who," in Milbank Memorual Fund 1956 Annual Conference, Proceedincs 78, 87, 84 (1957).

${ }^{17}$ E. Huntington \& L. F. Whitsey, The Builders of America 167 (I927). 
and money are bigger factors in getting to college than they are in getting into Who's Who. Nevertheless, college graduates probably have, on the average, more of the qualities we are now considering than have the general run of the population. In a comparison of graduates of 1930 with those of 1945 , Lauriat found that more of the recent graduates are marrying and higher proportions are having second and third children within ten years of graduation than among the earlier graduates. ${ }^{18}$ Ten years after marriage, the younger college women had a higher average number of children than did the older women twenty-five years after graduation. This would indicate a real increase in completed family for the younger group.

Recent figures for number of children born to couples with husband and wife at different educational levels are shown in table nine. Compared to the situation that existed thirty years ago, this table shows a remarkable change. Among couples in which both husband and wife have had at least one year of college education, over thirty-six per cent have had three or more children, a figure remarkably close to the forty-five per cent for couples neither of whom had more than eight years of grade school. The increase in the fertility of couples at higher educational levels may be due to the baby boom and may be temporary. But the decline in births among couples with grade school education appears to be permanent.

A number of small studies have been made of people at the higher educational levels, relating their fertility to some criteria of success. Table ten gives a sample of such studies at the college level, "success" being defined by the judgment of their

TABLE IX

Educational Levels of Married Couples in the United States, Husband Aged 30-44 Years, I957

\begin{tabular}{|c|c|c|c|c|c|c|}
\hline \multirow{2}{*}{ Educational Level } & \multirow[b]{2}{*}{$\begin{array}{l}\text { Couples } \\
\text { (thou- } \\
\text { sands) }\end{array}$} & \multirow[b]{2}{*}{$\begin{array}{l}\text { Percentage } \\
\text { of Total } \\
\text { Group }\end{array}$} & \multicolumn{4}{|c|}{$\begin{array}{l}\text { Percentage by Educational Lovel } \\
\text { of Couples with: }\end{array}$} \\
\hline & & & $\begin{array}{c}0 \\
\text { Children }\end{array}$ & $\stackrel{1}{1}$ & Children & $\begin{array}{l}3 \text { or More } \\
\text { Children }\end{array}$ \\
\hline $\begin{array}{r}\text { Husband: Elementary, } 0-8 \text { years.... } \\
\text { Wife: Elementary, 0-8 years...... } \\
\text { High School or College.... }\end{array}$ & $\begin{array}{l}3,807 \\
1,924 \\
1,883\end{array}$ & $\begin{array}{r}100.0 \\
50.5 \\
49.5\end{array}$ & $\begin{array}{l}16.5 \\
18.5 \\
14.5\end{array}$ & $\begin{array}{l}17.1 \\
15.3 \\
18.8\end{array}$ & $\begin{array}{l}25.0 \\
21.5 \\
28.6\end{array}$ & $\begin{array}{l}41.4 \\
44.6 \\
38.1\end{array}$ \\
\hline $\begin{array}{r}\text { Husband: High School, } 1-4 \text { years.... } \\
\text { Wife: Elementary, } 0-8 \text { years...... } \\
\text { High School, } 1-4 \text { years..... } \\
\text { College, } 1 \text { year or more.... }\end{array}$ & $\begin{array}{r}7,590 \\
899 \\
6,044 \\
647\end{array}$ & $\begin{array}{r}100.0 \\
11.8 \\
79.6 \\
8.5\end{array}$ & $\begin{array}{l}13.5 \\
13.8 \\
13.3 \\
15.6\end{array}$ & $\begin{array}{l}20.4 \\
20.1 \\
20.5 \\
19.8\end{array}$ & $\begin{array}{l}32.0 \\
28.1 \\
32.4 \\
32.9\end{array}$ & $\begin{array}{l}34.1 \\
37.0 \\
33.8 \\
31.7\end{array}$ \\
\hline 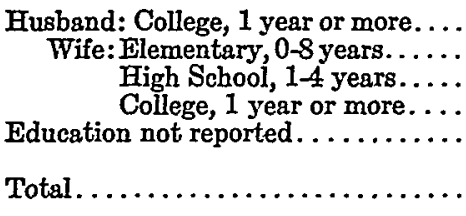 & $\begin{array}{r}2,933 \\
80 \\
1,479 \\
1,374 \\
132 \\
14,462\end{array}$ & $\begin{array}{r}100.0 \\
2.7 \\
50.4 \\
46.8\end{array}$ & $\begin{array}{l}13.5 \\
17.5 \\
12.8 \\
14.0\end{array}$ & $\begin{array}{l}16.3 \\
26.2 \\
17.7 \\
14.1\end{array}$ & $\begin{array}{l}35.0 \\
30.0 \\
34.9 \\
35.5\end{array}$ & $\begin{array}{l}35.2 \\
26.2 \\
34.6 \\
36.4\end{array}$ \\
\hline
\end{tabular}

Source: O.S. Bureau of the Census, Dep't of Commerce, Current Population Reports, Ber. P-20, No. 83, Aug. 4, 1858, tablo 13.

${ }^{18}$ Lauriat, Marriage and Fertility Patterns of College Graduates, 6 Eugenics Q. 17I (1959). 
TABLE $\mathrm{X}$

Fertility Differentials among Graduates of Harvard, Princeton, and Yale

\begin{tabular}{|c|c|c|c|c|c|}
\hline Degree of Success & $\begin{array}{l}\text { Number } \\
\text { of Cases }\end{array}$ & $\begin{array}{l}\text { Percentsge } \\
\text { Married }\end{array}$ & $\begin{array}{l}\text { Average } \\
\text { Number } \\
\text { Children } \\
\text { per Man }\end{array}$ & $\begin{array}{c}\text { Average } \\
\text { Number } \\
\text { Children per } \\
\text { Married Man }\end{array}$ & $\begin{array}{c}\text { Percentage } \\
\text { Childless } \\
\text { Couples }\end{array}$ \\
\hline 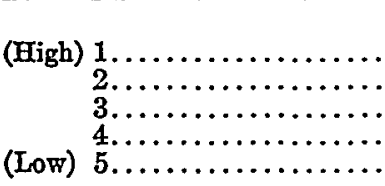 & $\begin{array}{l}\text { Hart } \\
120 \\
430 \\
735 \\
473 \\
131\end{array}$ & $\begin{array}{r}\text { Men } \\
93 \\
87 \\
87 \\
72 \\
58\end{array}$ & $\begin{array}{l}2.02 \\
1.76 \\
1.54 \\
1.03 \\
0.74\end{array}$ & $\begin{array}{l}2.17 \\
2.05 \\
1.78 \\
1.43 \\
1.28\end{array}$ & $\begin{array}{l}19 \\
18 \\
23 \\
36 \\
38\end{array}$ \\
\hline $\begin{array}{l}\text { (High) } \begin{array}{r}1 \\
\end{array} \quad \ldots \ldots \ldots \ldots \ldots \ldots \ldots \ldots \\
\text { (Low) } 3 \ldots \ldots \ldots \ldots \ldots \ldots \ldots \ldots\end{array}$ & $\begin{array}{r}338 \\
366 \\
54\end{array}$ & $\begin{array}{l}93.0 \\
86.7 \\
66.8\end{array}$ & $\begin{array}{l}1.97 \\
1.56 \\
1.09\end{array}$ & $\begin{array}{l}2.14 \\
1.80 \\
1.64\end{array}$ & $\begin{array}{l}15.7 \\
18.9 \\
22.2\end{array}$ \\
\hline 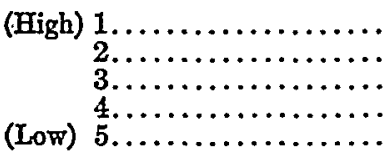 & $\begin{array}{l}140 \\
139 \\
138 \\
138 \\
137\end{array}$ & $\begin{array}{l}92.85 \\
85.70 \\
83.35 \\
83.35 \\
66.45\end{array}$ & $\begin{array}{r}2.27 \\
1.78 \\
1.63 \\
1.33 \\
.86\end{array}$ & $\begin{array}{l}2.44 \\
2.08 \\
1.95 \\
1.60 \\
1.29\end{array}$ & $\begin{array}{l}17.69 \\
16.80 \\
20.00 \\
32.17 \\
40.66\end{array}$ \\
\hline
\end{tabular}

Gource: Frgaericx Osborn, Prepace to Eugentcs 175 (2d ed. 1951).

classmates. Many questions can be raised about the methodology of these studies, but they were made quite independently and it is interesting to note the similarity of the results.

In 1955, Gutman and Bender made a study of ninety-five married graduates of the class of 1940 at Dartmouth. ${ }^{18}$ Within fifteen years of their graduation from college, these married graduates had an average of 2.43 children and many years of fecund life ahead of them. In reply to the question, what they considered their ideal family size, and assuming that the stated ideal represented their own plans, the average size of the intended family was 3.14.

While in college, these men had been rated by their instructors and other educational personnel for five groups of personality traits. In I955, coefficients of correlation were worked out showing the degree of association between number of children and the selected independent variables of personality. Only one of these variables appeared to be significantly related to fertility; for the degree of extroversion, the correlation was $48 \mathrm{I5}$. But the extroversion score was available for only forty respondents.

Studies of this sort are of considerable interest, but they are too limited and too small, even in the aggregate, to be accepted for more than an indication of possible trends.

The practice of fertility control has been general among the more-educated people in this country for a much longer period of time than among the less-educated. Findings on the present fertility of the more-educated may be somewhat more indi-

${ }^{10}$ Gutman \& Bender, Some Sources of Variation in the Family Size of College Graduates, 35 MrLbank Memoriat, Fund Q. 287 (I957). 
cative of permanent trends than are findings on the fertility of the less-educated. But such an assumption is hazardous in view of the postwar psychology and the great prosperity of the postwar years that were concomitant with the upsurge in births among the white-collar classes. We do not know how fertility would stand up in a period of depression. On the other hand, a considerable proportion of the lowereducational, the lower-income, and the lower-occupational groups have not yet accepted the practice of birth control, or if they have, their practice tends to be ineffective. If, as seems likely, the practice continues to spread, and if improved means of fertility control are developed, we might expect a further narrowing or even reversal of the differentials now favoring the least-educated.

No survey of this field would be complete if it did not touch on Terman's study of gifted children. ${ }^{20}$ In I92I, Terman and his associates picked something over 1500 children from the grade and high schools of certain larger California cities who, on the basis of their ability to pass intelligence tests, ranked in the top one per cent of the population of the schools. This gifted group has since been studied at five-year intervals, the last study having been made in 1955, when they were about forty-five years old. Classified by parentage, twenty-nine per cent were the children of professional people, a group who constituted only 2.9 per cent of the total population. Twenty per cent were the children of skilled laborers, a group who constituted 57.7 per cent of the population. When they grew up, 45.6 per cent of the gifted had become professional people by the age of forty-five-lawyers, teachers, judges, doctors, school and college administrators. They maintained their intellectual superiority; they led unusually normal and successful lives; they earned high incomes; they married superior wives; they have at least the average number of children for people in their income class. Their 2,452 children have an average I.Q. of 132.7 , as against an average score of I5I for the gifted.

Terman's study lends justification for the use of intelligence tests as criteria of socially useful qualities and offers encouraging indications that gifted people do not fail to reproduce.

b. Fertility within the middle group. In the past two decades, three major studies have been undertaken at a cost in excess of $\$ 100,000$ each to determine the differences in fertility practices and levels by social, economic, cultural, and psychological factors. The first of these was the Indianapolis fertility survey, conducted in 1941 under the auspices of the Milbank Memorial Fund. ${ }^{21}$ One of its purposes was to test certain hypotheses on the relation of social and psychological factors to fertility planning, status, and size of planned family. The study was based on a stratified sample of the $4 \mathrm{r}, 498$ native-white-Protestant couples in Indianapolis with the following characteristics: the marriage had occurred in the period $1927-29$, when the wife was under

so I L. M. Terman et al., Genetic Studies of Genius [Mental and Physical Thaits of a Thodsand Gifted Chmbren] (1925).

${ }^{21}$ Kiser \& Whelpton, Social and Psychological Factors Affecting Fertility: Stummary of Chief Findings and Implications for Future Studies, 36 MILbanx Memorial. Fund Q. 282 (1958). 
thirty years of age; each spouse had been married only once; each had at least an eighth-grade education; and the couple had lived most of its married life in a large city. The field study was made at the end of the depression, a period in which birth rates were the lowest in our history.

The findings indicated the traditional inverse or negative association of socioeconomic status and fertility when the group of "relatively fecund" couples was taken as a whole. When the couples that spaced and planned their children were considered as a separate group, a positive relation of economic security to the size of completely planned families was conspicuous. Correlations of fertility with personality characteristics such as feelings of personal adequacy, desire for freedom, interest in children, and rationality of behavior, were disappointing. Where these psychological motivations were found to relate to fertility, the relationship often resulted from the joint function with socioeconomic status.

In general, the Indianapolis study did not make many new contributions to our knowledge of personality variables as they relate to fertility; but it laid a groundwork of methodology that will be of value in future studies.

In March 1955, Freedman, Whelpton, and Campbell interviewed a national crosssectional sample of 2,713 married white women eighteen to thirty-nine years of age. In contrast to the couples in the Indianapolis study, these women had been for over ten years under the influence of the baby boom. The women were asked how many children they expected to have in their completed families and how they expected to achieve this size. The study found that fertility differentials have not only diminished, but that "some of the differentials, such as those associated with income, education, and place of residence, even show signs of disappearing."22 They found also a growing uniformity of attitude toward family size and an almost universal approval of family limitation as well as its widespread and effective practice by the white couples who need it. ${ }^{23}$ These, of course, offer a major explanation for the diminution of differentials.

This study did not attempt to correlate individual personality characteristics with fertility, probably because of the difficulty of defining and measuring these traits. For what is probably the most comprehensive exploration of the relationship between personality and fertility, we look at the third major study, that undertaken by the Princeton University Office of Population Research, the results of which are about to be published. ${ }^{24}$ This study sought, among other things, to isolate some of the causal connections between fertility behavior and certain cultural and psychological variables. ${ }^{25}$ After several pretest field surveys, the main investigation was launched in late January 1957. It covered 1500 native white women, currently and only once married, who had had their second child within six months of the

${ }^{32}$ FREEDMAN ET AL., op. cit. supra note 3, at 273.

so Id. at $40 \mathrm{r}$.

"Charles F. Westoff, Robert F. Potter, Jr., Philip C. Sagt \& Elliott G. Mishler, Family Growth in Metroporitan America (to be published).

${ }^{25}$ Westoff, A New Study of American Fertility, 2 Eugenics Q. 229 (I955). 
initial interview. Women with two children were selected on the assumption that their expectations of completed family size will be a reasonably good predictor of reproductive behavior in the near future. Eight personality variables were measured: I) anxiety, 2) nurturance (meaning helpful or sympathetic attitudes toward others), 3) impulse-self-control balance, 4) self-acceptance and insight, 5) compulsiveness, 6) tolerance for ambiguity, 7) cooperativeness, and 8) need to achieve.

Again, the results are disappointing. For only three of the ten hypotheses relating personality and fertility are the correlations statistically significant. These three are manifest anxiety and compulsiveness, which are negatively associated with fertility, meaning that people with these qualities tend to have fewer children; and ambiguity, tolerance-i.e., tolerance for disorder, etc., which is positively related to fertility. Even these three statistically significant correlations are so small, however, as to account at best for only one per cent of the variance in number of children desired.

In summary, the efforts made to date to find relationships between personality and fertility have been disappointing. In three major studies covering large segments of the population, no substantial correlations have been found between fertility and traits of personality. Changes in the quality of the middle group who comprise the great majority of our people may greatly affect the future of the country. But we do not know what, if any, changes of this sort are taking place. We have ample evidence that social and psychological factors of the environment affect people's attitudes towards size of family. It would be strange if people of different types reacted to these influences in just the same way.

c. Fertility at the lowest levels of quality. The mentally ill, the mentally deficient, and the physically abnormal are at the lower levels of human quality. It is now generally agreed that heredity plays a major part in most forms of mental illness and in many forms of mental deficiency and physical abnormality. But we are not at this time considering causes. Our concern is with the fertility of a group whose children are bound to be injured by the low quality of their parents, whether by reason of their poor heredity or because their parents will be unable to give them proper care.

Until quite recently, the fertility of this group was a matter of opinion rather than of knowledge, and that opinion took extreme and opposite forms. In the middle of the nineteenth century, Morel expounded a doctrine of degeneration, under which weaknesses, mild at first, became worse in each succeeding generation, until the stock was wiped out by its inability to reproduce. ${ }^{28}$ At the turn of the century, the opposite theory was widely held. Studies, later shown to be inadequate, seemed to indicate that abnormal stocks were more fertile than the normal stocks in the community. Fears were expressed by eugenists and others that the

${ }^{26}$ B. A. Morel, Tratte des Degenerescences physiQues, intellectuelless et Morales de L'espece humaine [Treatise on the Physical, Intellectual and Moral Degenerations of the Human Species] (I857). 
race was deteriorating, perhaps quite rapidly. But more recently, Dahlberg in Sweden, ${ }^{27}$ Dayton in Massachusetts, ${ }^{28}$ Essen-Möller in Lund, ${ }^{29} \mathrm{Kallmann}$ in Germany, ${ }^{30}$ and Böök ${ }^{31}$ and Sheldon Reed and others ${ }^{32}$ in this country, using refined statistical methods on larger samples, came to the conclusion that the fertility of the mentally ill was in general lower than that of the rest of the population. Dr. Aubrey Lewis summarized these findings in a recent article in the British Eugenics Review, noting that, ${ }^{33}$

of the two commonest and gravest mental disorders, manic-depressive psychosis is characterized by approximately normal fertility, and schizophrenia by much lower fertility than normal, largely because of lessened capacity for marriage. Very little is known about the fertility of people with neurotic disorders, but there is no evidence that it differs greatly from the normal.

For a number of years the Dight Institute for Human Genetics at the University of Minnesota has been conducting a study of the fertility of patients at the State School for the Feebleminded and of the fertility of their relatives. This study was summarized in 1954 in the following terms: ${ }^{.34}$

We conclude that the genes for severe mental deficiencies behave in the same way as do the genes for severe physical defects. They tend to be gradually eliminated from the population and presumably are replaced by new mutations from normal genes.

This statement may not take sufficiently into account, however, the contunuous distribution of deleterious genes by persons who are carriers.

If differential fertility is adversely affecting the quality of the population at the present time, it would be that caused by a high rate of fertility among the larger group of people who might be classed as the socially inadequate-those families who are perennially on the relief rolls, the constant problem of the social worker. Unfortunately, our information on the fertility of this group is meager. It seems impossible to say at this time whether its rate of fertility is higher or lower than that of the general population.

\section{Conclusions}

The control of death and, to a somewhat less extent, the control of fertility, are now being practiced by perhaps a quarter of the world's population. These practices are interdependent; we cannot for long have one without the other. Since people

${ }^{37}$ Dahlberg, Die Fruchtbarkeit der Geisteskranken [The Fertility of the Mentally Diseased], 144 Z'schr. f. d. Ges. Neurol. U. PsYchiat. 427 (I933).

${ }^{28}$ Dayton, Size of Family and Birth Order in Mental Disease, 24 Studies in Quantrtative AND Cultural Sociology I23 (1930).

${ }^{20}$ Essen-Möller, Mating and Fertility Patterns in Families with Schizophrenia, 6 EugENICs Q. 142 (1959).

${ }^{80}$ Fritz J. Kallamann, The Genetrcs of Schizophrenia (1938).

${ }^{31}$ Böök, Fertility Trends in Some Types of Mental Defects, 6 Eugenrcs Q. Ir3 (1959).

${ }^{33}$ S. C. Reed, E. W. Reed, \& Palm, Fertility and Intelligence Among Families of the Mentally Deficient, I Eugenics Q. 44 (1954).

${ }^{33}$ Lewis, Fertility and Mental Illness, 50 Eugenics Rev. 9匚 (1958).

${ }^{32}$ S. C. Reed, E. W. Reed \& Palm, supra note 32, at 52. 
everywhere want lower death rates, it seems likely that both practices will spread, perhaps quite rapidly, throughout the whole world. It is, therefore, important to examine what effect these practices may have on the quality of populations.

Historically, the control of deaths has always preceded an effective control of births. Death rates go down first, birth rates go down later. During the period of unbalance between the two, there are rapid increases in population. We have recently witnessed just such an increase in the numbers of people of European descent. Now their growth has stabilized at low levels of births and deaths. At the same time, a similar cycle is beginning in Asia, Africa, Central and South America, and the Arab states. As their numbers go up, the proportion of people of different races and cultures is changing, and thus changing the aggregate quality of the world population. These rapid increases in numbers also affect the quality of the populations concerned, since they handicap the economic improvement necessary for strengthening educational and cultural facilities.

In Europe, England, North America, Australia, and now in the Soviet Union and Japan, deaths are uniformly at a low level, but there are still considerable variations in the use and effectiveness of birth control. Some groups are increasing in proportion to others, and these changes may have a considerable effect on quality. But they are of a temporary nature. No final assessment of the effect of population control on human quality can be made until both low death rates and low birth rates are firmly established.

In the United States, the rapid growth of the past 200 years has been accompanied by an even more rapid increase in production of goods and a constant advance in the level of living. It is not possible to assess the part played by rapid growth alone. With our present large population, it is likely that future growth may increasingly have a retarding effect on the improvement of levels of living, and hence indirectly on the quality of our people. But for a long time to come, this will be masked by continuing increases in production.

Birth control started, in the United States, among high-income, educated, urban groups, and spread gradually to people at lower levels of income and education and to those on the farm. Even now, when eighty-five or ninety per cent of married couples use some form of fertility control, contraception is less effective among the less-educated, lower-income groups, so that there are still substantial variations in rates of increase. Differentials seem to be narrowing, but the fact remains that at the present time, one-fifth of our children are being brought up in homes with an annual family income of less than $\$ 3,000$. Since the educational level of parents and the environment of the home are both affected by poverty of resources, there are here serious implications of an injurious effect on the quality of the population, springing from the unequal practice of birth control.

Recent studies of the effect of population control within the various socioeconomic classes give a somewhat hopeful picture of a trend that appears to be 
developing. At the upper levels of quality, the birth rates of men in Who's Who and of college graduates appear now to be at or near replacement levels, as against rates way below replacement levels thirty years ago. At the lowest levels of quality, among the mentally deficient and defective, rates of reproduction appear to be low, due in part to more time spent in institutions and to low marriage rates. In the great middle group, who comprise most of our population, recent extensive studies have developed hardly any information as to variations in fertility between couples with different personal qualities. It is in this group that the quality of future generations will be mainly determined. There is here an important field for further study.

Findings on fertility differentials in the United States during the past forty years appear, in most cases, to indicate that they have done some injury to population quality. But differentials in fertility are changing rapidly as birth control becomes more widespread and more effective. New trends are appearing, and some of these are distinctly favorable to the improvement of the quality of our people from one generation to another.

According to Webster, eugenics is "the science which deals with influences, primarily those admitting of social control, that improve inborn or hereditary qualities in a series of generations of a race or breed, especially of the human race"; and euthenics is "the science having to do with the betterment of living conditions to secure more efficient human beings."35 The effectiveness of eugenic and euthenic programs will depend to a large extent on the direction of population trends. The field of study of the effects of population control on population quality is in its infancy. It is an interdisciplinary field, involving the demographer, the psychologist, the economist, the social anthropologist, and the student of human genetics. In this preliminary statement, little mention has been made of human genetics. There is at present a large theoretical structure on the genetics of population, but little as yet of specific information about variations in psychological characteristics. Knowledge is increasing in all these fields. As this knowledge accumulates, and the interrelations of its various aspects become better understood, the major importance of this field will become increasingly recognized. Practical applications will begin to emerge, and their direction may ultimately determine the future of the race.

${ }^{35}$ Webster's New Internationat Dictionary Unabridged 880, 883 (2d ed. 1950). 